GRZEGORZ SZPILA

Jagiellonian University in Kraków

grzegorz.szpila@uj.edu.pl

\title{
ANGLICISMS IN CONTEMPORARY UPPER SORBIAN - ENGLISH / ENGLISH - UPPER SORBIAN DICTIONARIES
}

Keywords: Anglicisms, dictionaries, Upper Sorbian, English

\begin{abstract}
This paper investigates four bilingual English - Upper Sorbian / Upper Sorbian - English dictionaries regarding the presence of Anglicisms therein. The paper describes the place of Anglicisms in the macrostructure of the lexicons as well their treatment within entries either as headwords or counterparts. The paper enumerates their numerical presence as well as the types of borrowings, and the other processes responsible for enriching the lexis of Upper Sorbian with English lexical elements as revealed in the dictionaries. The paper discusses the information regarding the adaptation of English lexical items in Upper Sorbian (phonetic, graphic, morphological and semantic) that can be obtained from the lexicographic works.
\end{abstract}

\section{Introduction}

It is not surprising that linguists have for a considerable time been interested in analyzing the interlingual relationships between English and other world languages in the light of the status of English as the modern lingua franca and its influence on other tongues on many a level. One of the domains in which the English language exerts an impact on other languages is undoubtedly lexis, which has arguably attracted the most attention on the part of language researchers studying the results of language contact. This perhaps is not surprising since English is believed to be the major source of lexical borrowings in the languages studied (Furiassi 2003: 121), a matter which is not restricted only to languages spoken in Europe. 
The need to research the English influence on Slavonic languages was formulated a long time ago (Filipovič 1974: passim) and since then the contact between the languages of these two different groups has also been analyzed with regard to the presence of English loanwords in Slavonic languages. Indeed the lexical impact of English on the vocabularies of many European languages was described in A Dictionary of European Anglicisms (Görlach (ed.) 2005), arguably the most important work of this type and scale compiled so far. The dictionary, somewhat surprisingly, does not provide information regarding the lexical borrowings from English in all the European languages. One of the languages not considered is Upper Sorbian (together with Lower Sorbian). The absence of the Sorbian component in A Dictionary of European Anglicisms is not of course intentional on the part of the dictionary's compilers but can be rationalized, and perhaps explained, either by the extremely limited research into English borrowings in Upper and Lower Sorbian and/or the assumption that the English loanwords in German penetrate the Sorbian languages profoundly enough to sanction generalizations concerning the two Slavic languages on the basis of the impact English has exerted on German and the influence of the latter on Upper and Lower Sorbian.

It may be safely stated that the existence of English words in the Sorbian languages is to a large extent conditioned by the contact of the latter with German (cf. Völke 2006: 43). Nevertheless, we cannot ignore the fact that apart from the indirect contact between the English lexis and Upper Sorbian via German, the Slavonic language is in direct contact with English as well. The latter type of relation needs further examination but such an analysis goes beyond the scope of the present exploration.

The aim of this paper is to highlight the differing lexicographic descriptions of Anglicisms in the selected dictionaries from the perspective of the four major adaptation processes which regulate the assimilation of foreign words into target languages and which at the same time demonstrate the degree of adaptation of the foreign lexis. Linguists studying the process of borrowing usually differentiate the following types: phonetic, graphic, morphological and semantic adaptation. We have to bear in mind that words are adapted gradually and do not undergo all the processes while being accommodated in the system of the target language, which oftentimes is attested in their lexicographic description. The lexicons selected for the present study may give us some, but not necessarily all, the information concerning the degree of adaptation, because, for instance, they are not specialized dictionaries and so they do not provide information about the pronunciation, nor the etymology of Anglicisms this is also the case with other foreign lexical items. More precise and exhaustive information could be obtained from dictionaries of foreign borrowings in Upper Sorbian, which would have a greater focus on aspects of assimilation, including, for instance, information about the etymology, which is conspicuously absent from the bilingual dictionaries discussed here. However, no dictionary of English borrowings exists for Upper Sorbian, nor is there a dictionary of foreign words available in this Slavonic language, nor a genuine monolingual Upper Sorbian dictionary in which it would be possible to find further information about borrowed items. Therefore, when analysing any lexicographic material we have to rely on all and every piece of information that is available in the description of headwords and their counterparts 
in the target language. The analysis of the Upper Sorbian dictionaries can help to partially establish the status of Anglicisms in this tongue and should without doubt be supplemented by further lexicographic studies of the available dictionaries as well as other sources in order to attempt to ascertain the situation of English lexical elements in Upper Sorbian.

The dictionaries chosen for the present analysis are:

Stone G. 2002. Hornjoserbsko-jendźelski słownik. Budyšin. = HJS

Wornar E. 2007. Jendźelsko-hornjoserbski šulski słownik. Budyšin. = JHŠS

Richardson K. 2009. Jendźelsko-serbski słowničk za zakładnu šulu. Budyšin. = JSSZŠ

Strauch M. 200o. Sorbian [Wendish]-English / English-Sorbian [Wendish]. New

York. $=$ SEESD

\section{Macrostructure}

All four dictionaries have the same general structure: all are bilingual, contemporary, general, synchronic lexicons, which are semasiologically orientated. Jendźelskoserbski słowničk za zakładnu šulu is an exception in that it is also in part an onomasiological dictionary: it arranges the headwords within 20 lexical fields. Also it seems to be the least general as it is not only limited in scope by its size (100o headwords) but also and more importantly by the target user - primary school students (JHŠS is also geared towards the school user). The other three are examples of bilingual dictionaries par excellence.

The megastructure of HJS, JHŠS and SEESD is similar, except the A-Z list of headwords also contain the outer texts (Adamska-Sałaciak 2013: 219). The latter consist of Zawod (JSSZŠ); Abbreviations/Wužiwane skrótšenki, The Upper Sorbian Alphabet (SEESD); Preface, Abbreviations, the Upper Sorbian Alphabet, Upper Sorbian Pronunciation and Grammar (HJS); Zawod, Přispomnjenja..., Skrótšenki a kwalifikatory and an extended lexico-grammatical section (JHŠS).

In none of the dictionaries is there explicit information concerning the type of vocabulary that forms the macrostructure of the lexicons. Nor do they make any reference to borrowings from English, nor from any other languages, into Upper Sorbian. It seems that English loanwords are taken for granted and there is no marked difference between the treatment of English and Upper Sorbian headwords/ equivalents, which becomes evident in the analysis of the microstructure.

The corpus collected on the basis of the four dictionaries contains over 500 English lexical items (501). The material does not distinguish between Anglo-Americanisms and Briticisms (cf. Wanzeck 2010: 133), and although further analyses of English borrowings in Upper Sorbian could perforce make such a distinction to establish the relation between the two types of words (and the impact of British and American English on Upper Sorbian), it seems that in most cases such distinctions are impossible and/or futile. Additionally, the Anglicisms in Upper Sorbian are not differentiated on the basis of their etymology: both historically English (baby, byte, 
nylon, šerif) and non-English (bikini, curry, kiwi, kayak, wigwam) words in Upper Sorbian are treated in the same manner. The material analyzed does not include proper names either. All the words in my corpus are in consequence called Anglicisms. The table below lists the four dictionaries used for the analysis and shows the number of Anglicisms therein and their percentage vis à vis the total number of headwords. It has to be noted that the total number of Anglicisms takes into account the headwords and the equivalents.

\begin{tabular}{lccc}
\multicolumn{1}{c}{ Dictionary } & Word content & $\begin{array}{c}\text { Number of } \\
\text { Anglicisms }\end{array}$ & $\begin{array}{c}\text { Percentage of } \\
\text { Anglicisms }\end{array}$ \\
\hline $\begin{array}{l}\text { Sorbian[Wendish]-English/Eng- } \\
\text { lish-Sorbian [Wendish] }\end{array}$ & circa 4500/3200 & $166 / 161$ & $3.7 \% / 5 \%$ \\
$\begin{array}{l}\text { Hornjo-serbski słownik } \\
\text { Jendźelsko-serbski slowničkzazak- }\end{array}$ & circa 20000 & 169 & $0.8 \%$ \\
$\begin{array}{l}\text { tadnu šulu } \\
\text { Jendźelsko-serbki šulski słownik } 1000\end{array}$ & circa 15000 & 46 & $4.6 \%$ \\
\end{tabular}

The statistics show different numbers of Anglicisms identified in the dictionaries. The dictionary most abundant in Anglicisms is Wornar's dictionary, while the learner's dictionary has the fewest number of English elements although percentagewise this dictionary is the most saturated with Anglicisms. ${ }^{1}$ The low number of Anglicisms in this dictionary is motivated by the target user but nevertheless shows the penetration of English elements into the lexis treated as the core vocabulary for school children. The first two dictionaries in the table contain almost the same number of Anglicisms but the saturation of Strauch's dictionary with Anglicisms is clearly greater.

Anglicisms show different distributions within the dictionaries. That is to say, some Anglicisms appear in all four and others only once in one of the four lexicons. The following enumeration lists Anglicisms that have been excerpted from all four lexicons: alligator, anorak, baseball, basketball, bus, disco, fairny, golf, helicopter, hobby, hokej, interview, jeans, kanu, keks, lift, partner, piknik, pulower, reporter, rowdy, šampun, slogan, sport, start, tabu, tenis, test, toast, traktor, trend, t-shirt, tunl, wagon. Almost as frequent are the following lexemes: baby, bara, blidotenis, bos, camping, cent, charterowy, cowboy, design, designer, dollar, esej, fan, farma, firma, fit, fitness, fulm, hot dog, import, inch, jazz, job, kenguruh, keyboard, klub, lady, layout, lord, manager, medije, mikrofon, okay, party, pony, poster, punt, rugby, shortsy, slum, squash, steak, teenager, tramwajka, volleyball, whisky. On the other hand, many an Anglicism is registered only once, for example: chipsy, cornflakes, species, shake (SEESD); clan, cracker, cutter, flanel, freak, gag, jumbojet, smog, speedway, sterling, unca, yuppie (HJS); Halloween, inlineskaty, monster (JSSZŠ); kiwi, linolej, spleen, tweed, wigwam (JHŠS).

1 In comparison Wot A do Ž. Słowničk za zakładnu šulu (Langerowa, Šołćina 2007) inlcudes 32 Anglicisms. 
As far as English borrowings are concerned it is not surprising that the vast majority of the headwords are nouns, followed by adjectives and verbs, with other classes being extremely rare amongst the borrowed lexical units (cf. Onysko 2004: 61; Kowner, Rosenhouse 2008: 12). The dictionaries reflect this tendency very well: they contain $84 \%$ of nouns, $10 \%$ of adjectives and $6 \%$ of verbs, of which some examples are listed below. ${ }^{2}$ The high percentage of adjectives in comparison with verbs is a result of the application of derivational processes to English bases, and such derivatives are counted in this analysis as borrowings as well. Adverbial/adjectival elements are represented by okay, and $h i$ is classified as a borrowed interjection. Not all the dictionaries register all the major parts of speech, for example, JSSZŠ does not list any verbs.

HJS: nouns: anorak, album, bojkot, clown, tiket; adjectives: crossowy, fair, golfowy, wirtualny verbs: bluffować, boksować, campingować, padlować, sprintować, šampunować, šarterować.

JHŠS: nouns: baby, bikini, bos, bypass, derby, email, adjectives: fitnessowy, hobbyjowy, recyclujomny, sportowy, zoomowy; verbs: boykottować, charterować, faksować, kidnapować, klonować.

SEESD: nouns: broiler, camping, cent, cowboy, designer, hamburger, inch, verbs: interviewować, managować, padlować, picknikować; adjectives: fit.

JSSZŠ: nouns: comic, keks, kompjuter, monster, poster, snowboard, šampun; adjectives: busowy, cejdejkowy, comicowy, kompjuterowy, tenisowy.

The selection of Anglicisms for this analysis included all types of words, both monomorphemic and multimorphemic, including compound words. In my material there are no formulaic expressions, which the dictionaries in question fail to register. It has to be noted that certain Anglicisms appear in many open collocations in the dictionaries yet not as headwords or equivalents of the headwords, for example, denim - jeansowy płat (HJS), contact lenses - kontakne čoćki (JHŠS).

Simple words are illustrated by, for example, acre, baby, bob, bos, clown, comic, dress, fair, fan, freak, gin, sprint and others. Complex words can be exemplified as follows: bowling, camping, gangster, komputer, kontejner, manager, rewolwer and many others. The following are examples of compound words: babysitter, barkeeper, basketball, baseball, cornflakes, countdown, cowboy, gentleman, grapefruit, hot dog, know-how.

These examples represent Anglicisms in the dictionaries in their original forms. Nevertheless, the lexicons show examples of multimorphemic lexical items derived according to Upper Sorbian word formation rules. Such words are derived either from simple or complex words in English, for example, comicowy (US comic < Eng. comic + US. -owy), editěrować (US. editěr < Eng. edit + US. -ować), eksportować (US. export < Eng. export + US. -ować), fairnosć (US. fair < Eng. fair + US. -ny, -osć), grilowanje (US. gril < Eng. grill + US. -ować, -nje).

2 The statistics presented here confirm my observations (Szpila [forthcoming]) concerning the use of Anglicisms in the Upper Sorbian press in the years 2013-2015. 
The vast majority of the words are borrowings, that is lexemes represented in the lexicons either in their original forms or adapted shapes. Another category are calques and semi-calques created on the basis of English lexical items (cf. Obara 1989) and reinforced by their German calqued or semi-calqued counterparts. Calquing is considered the other major source of new elements in a language (cf. Onysko, Winter-Froemel 2011: 1552), but examples of calquing and semi-calquing in the dictionaries are rare, although the following do exist (some can be classified as phraseological calques and semi-calques): charterowy lèt (Eng. charter flight), coologiska zahroda (Eng. zoological garden, zoo), hodowy pudding (Eng. Christmas pudding), podłoha za myšku (Eng. mousepad), tenisowy hrajer (Eng. tennis player), popsěw (Eng. pop song), pophudźba (Eng. pop music), kameramuž (Eng.cameraman), mikrožołma (Eng. microwave), wirtuelna realita (Eng. virtual reality), kisały dešć (Eng. acid rain) as well as pfadfinder (Eng. pathfinder), which is a borrowed calque from German (Germ. der Pfadfinder). I found only one pseudo-Anglicism in the dictionary - handy - a classic example of this type of creation in German is also used in Upper Sorbian.

The collected words can be classified into various thematic classes, representing the domains which make use of English words in the process of nomination (Kleparski 2001: 22; Kovács 2008: 181). English borrowings in a foreign language can be grouped into many different thematic categories of which I have chosen only a few, those which to my mind best represent the lexical domains most significantly affected by English in the four dictionaries. My observations concerning the vocabulary domains with English loanwords confirm Völke's (2006: 38) remark that in Upper Sorbian we can find new lexical items of foreign origin in arguably all lexical fields.

Sport: aerobika, badminton, baseball, basketball, blidotenis, bob, bokser, bowling, derby, golf, hokej, krawl, kriket, rugby, skateboard, squash, surfowar.

Clothes: bikini, blazer, dress, jeansy, kilt, overall, pulower, pyjama, shorts, slip, $t$-shirt. Transport: awtobus, jeep, jumbojet, lokomotiwa, tramwajka, trolleybus, wagon.

Technology: byte, cejdejka, email, hacker, harddisk, hardware, high-techowy, internet, joystick, kompjuter, layout, monitor, notebook, online, processor, software.

Music and entertainment: bas, disco, film, jazz, musical, reggae, rock, rum.

Food and drink: biskwit, chipsy, coca-cola, cornflakes, curry, drink, gin, grapefruit, hamburger, pudding, hot dog, keks, ketchup, kiwi, popcorn, porridge, roastbeef, steak, toast, whisky.

Lifestyle: fitness, Halloween, hippy, hobby, hooligan, party, piknik, rowdy, skinhead, yuppie.

\section{Microstructure}

As was the case with the megastructure and macrostructure, the dictionaries do not differ much from one another when it comes to the form of their microstructure. Although Jendźelsko-serbski słowničk za zakładnu šulu always provides each 
headword with example sentences in English and Upper Sorbian (for example, Ćeta Lizzy, wuj Bill a baby bydla na burskim statoku, Widźiš poster mojeje najlubšeje popoweje skupiny, Dźensa snědam toast), this feature is entirely absent from SEESD and only occasionally appears in the other two dictionaries (for example, Zličbowanki so wše z kompjuterom pisaja in JHŠS).

The entries in the four dictionaries provide equivalents, occasionally together with a periphrastic semantic explication of the concepts. JHŠS is the only lexicon that includes information concerning the pronunciation of English words as headwords. The entries may contain a certain amount of grammatical information and collocations, but the English borrowings as mentioned earlier are not treated as a special category of words, hence their entries are only as informative as the other entries.

In Wornar's dictionary we encounter an interesting lexicographic situation. For some Anglicisms the author provides extended definitions, which hardly function as translational equivalents. The case in point is the lexeme adapter, which has the following explanation: "tykač z wjacorymi móžnosćemi přizamknjenja" for the meaning of 'a device for connecting two parts, such as plug' (Stone adduces the Anglicism adapter/adaptor in the sense of 'record player'). This is surprising as Prawopisny słownik hornjoserbskeje rěče (Völkel 2005) and Deutsch obersorbisches Wörterbuch neuer Lexik (Jentsch, Pohontsch, Schulz 2006) no longer distinguish the two meanings and introduce the Anglicism for both senses. Similarly, Wornar does not register the Upper Sorbian baby as an equivalent for baby despite its presence in many a Sorbian dictionary. This strategy may be explained by the prescriptive approach to using foreign lexical items to the detriment of native vocabulary (cf. the lack of bachelor, bike, box). However, it may lead to situations when English loanwords are registered as equivalents of words other than their English etymons, for example, blancmange is translated as puding, but pudding only as dessert and pojédz; mikser is paired with the English blender but not with mixer ("kuchinska mašina"). Another reason may be simply that with the vocabulary of Upper Sorbian changing so rapidly the dictionary makers hesitate to include Anglicisms for fear that the latter might be ephemeral borrowings and so not merit a place in a lexicon.

\section{Pronunciation}

It is impossible to establish the way English words are pronounced by native speakers of Upper Sorbian by analysing the Anglicisms in the four dictionaries: they do not contain information about the pronunciation of Anglicisms (they may give the pronunciation of English words as headwords). The only information pertaining to the issue of phonetic assimilation may be obtained from the spelling of Anglicisms which in some cases - it may be assumed - reflects their pronunciation. In other cases we have to take that bilingual speakers of German and Upper Sorbian follow the German pronunciation of English loanwords. The spelling of well-established Anglicisms, as mentioned, suggests their pronunciation, for example: biskwit, bojkot, kontejner, kompjuter, ketčup, krawl, kwis, hokej, pulower, skawt, skeč, šampun, šarter, 
šerif. However, it remains to be ascertained if the accent of the English counterparts has changed or not and if so, how. It has to be said that because the spelling is not consistent (for instance, ketchup, container and others) we cannot be sure either if the pronunciation changes alongside the change in graphic shape simply by looking at the dictionaries.

\section{Spelling}

As far as the spelling of Anglicisms is concerned, we observe that English loanwords either retain their original spelling (the vast majority) or change to adhere to the spelling rules of Upper Sorbian, in which case the graphic adaptation reflects also the assimilation on a phonetic level (see above): dźungl, faks, skě́, šampun, skeč, in which English sounds are replaced by Sorbian phonemes (for instance: /dz/, /tg/, / $/>$ $/ \mathrm{dz} /, / \check{c} /, / \check{s} /$ ). The changes are conditioned by the correspondence between letters and sounds in Sorbian (for example: " $c$ " =/ts/) as well as by the non-existence of certain letters or combinations thereof in the target language (for instance: "ph", "x"). The main processes regarding orthographic adaptation amongst Anglicisms in the selected material are as follows:

- Replacement of letters: bokser, kompjuter, kombajn, koncern, klawn;

- Elimination of double letters: bas, bos;

- Reduction in clusters of letters: ticket, gril, hokej, joker, trick;

- Lower case spelling: aids, american football, internet;

- Elimination of hyphenation or solid spelling: comicstrip, jumbojet, soapopera, widejohra, widejorekorder.

We should note at this point that the dictionaries discussed here may provide two versions of the orthographic forms, such as kwisowy/quizowy, charterowy/šarterowy, esej/essay (SEESD), whereas elsewhere they reflect the alternative spellings in English itself, such as hot dog vs. hotdog, and finally different dictionaries may even vary in the way they register the spelling of Anglicisms: biscuit (HJS) vs. biskwit (JHŠS), boycott in HJS vs. bojkot (JHŠS), scout (SEESD) vs. skawt (HJS). The four dictionaries eloquently demonstrate that the spelling of some Anglicisms is not standardized into one form only (container/kontejner, computer/kompjuter/komputer, volleyball/wolejbul) but otherwise adaptation on the orthographic level seems regular and predictable.

\section{Morphology}

The four dictionaries provide scant information regarding the grammatical aspects of Anglicisms. The grammatical sections of the entries are limited or nonexistent (JSSZŠ), although two dictionaries JHŠS and HJS provide grammatical 
information about the gender and inflection of the headwords, including those which are Anglicisms (in SEESD the grammatical information is random and occasionally erroneous). As far as Anglicisms are concerned, the headwords provide information concerning parts of speech, gender and inflection. The part of speech is assigned indirectly in HJS as nouns are described in terms of gender (for example, bas, bokser, bulldozer are masculine nouns; hostess, jachta and padla are feminine nouns; bluffować, boksować and campingować are verbs); in JHŠS the grammatical information is available only for English headwords and not for the equivalents, but it is direct. There is also information regarding inflection: the open classes are crossreferenced with the inflectional paradigms of the outer matter of HJS but in the case of uninflected nouns or adjectives the information is provided in the microstructure of the headwords, for example: fair and jury are classified as indeclinable.

The derivatives automatically imply the declinability of forms, which can be observed in the case of nouns, adjectives and verbs: campingowanišćo, fairnosć, startowc; busowy, centowy, comicowy, crossowy, fitnesowy, golfowy, hobbyjowy, njefairny, padlowy; bluffować, boksować, joggować, toastować. Derivation concerns adjectives (and in consequence adverbs) and verbs. Nouns are borrowed without the necessary prefixal-suffixal formatives unless further semantic senses are to be derived, such as feminine nouns from English genderless nouns, for example, designer/designerka, partner/partnerka, reporter/reporterka, steward/stewardka. Surprisingly, such feminine derivatives are extremely rare in the lexicons analyzed. We can only speculate about the grammatical features of other forms, as no grammatical information is provided. Therefore, Anglicisms such as cool and fit which do not bear Upper Sorbian derivational suffixes could be treated as indeclinable, which in fact they are. Other features can be ascribed to Anglicisms only on the basis of the grammatical (inflectional and gender) system of Upper Sorbian.

In the material I noted only two specific examples concerning the morphological process of adaptation, namely the process of the deplurization of nouns, which involves ignoring the original plural suffix and adding a native marker of plurality, and examples include: chipsy, jeansy, legginsy and shortsy (but cf. jeans in SEESD and shorts in JHŠS). The reverse process can be exemplified by dint of the lexemes pyjama and overall, whereby the English plural suffix is eliminated.

\section{Semantics}

The dictionaries discussed are typical bilingual dictionaries in that they provide only synonyms for the headwords. The equivalents when English words are headwords are almost always corresponding Anglicisms in Upper Sorbian, for example: hamburger - hamburger, lobby - lobby, volleyball - volleyball in SEESD, if, that is, Upper Sorbian has a borrowing as an equivalent (but cf. cider - jablukowe wino in HJS). Occasionally, English words may be translated by means of another English word as an Anglicism, for example: briefs - slip, hooligan - rowdy, rollerblade - inliner (HJS). 
It should be noted that recent dictionaries have introduced other equivalents for the above words, for example, Deutsch-obersorbisches Wörterbuch neuer Lexik (2006) cites hooligan as an Anglicism in Upper Sorbian. The dictionaries are not consistent in registering Anglicisms, as some provide them as equivalents, other do not, preferring to suggest native words as counterparts: cf. babysitter - hladar/ka, dohladowar/ ka dzěći in SEESD vs. babysitter - babysitter in HJS.

English lexical items are usually provided with only one equivalent (Anglicism), but in some cases they are given more than one; that is, apart from an Anglicism the dictionaries list Upper Sorbian lexemes as counterparts, for example: babysitter - babysitter, pěstońča; canoe - padlowanski čołm, kanu; clan-clan, wulkoswójba; layout - layout, naćisk; sticker - nalěpk, sticker (HJS); band - kapała, hercy, band; baby - ćěšenk (SEESD). Naturally, more equivalents appear when the English words are polysemous, as is the case with trip - jězba, wulèt, pućowanje; trip; zakopnjenje. It may happen that one English word is paired with different equivalents, each of which contain an Anglicism, the case in point being comic which is translated as comic and comicowy zešiwk in JSSZŠ, comic, comicstrip in JHŠS, and additionally as comic-zešiwk in SEESD.

In very infrequent cases English words and Anglicisms are additionally explained in differing ways, for example: AIDS (Acquired Immune Deficiency Syndrome); derby derby (tradicionelne konjace wubědźowanje); squash - (hra) squash; kilt - šotiska muska suknja; know-how - praktisko-techniska wěda, nazhonjenja (SEESD); sterling (britiski ménowy system) sterling (HJS).

In each case the meaning of the headword is clearly conveyed. A problem only presents itself when English might have influenced the existing words of foreign origin in Upper Sorbian by extending their senses, which is illustrated by album - album (HJS); pirate - pirat and virus - wirus (SEEED), a fact which is not mentioned in the dictionaries. In such cases it is not certain which sense of the English word the Upper Sorbian lexeme may have and if and how the words have enriched their semantics in the way, for example, Polish lexemes have under the influence of English (but in JHŠS virus - wirus is in the medical sense only). Similarly, some polysemous senses of Anglicisms are not registered, as in application - pisomna próstwa, nałožowanje (HJS), where another sense of application (aplikacija) is not registered. The explanation may be quite simple yet at the same time informative, because we may assume that the dictionaries did not register some senses as they were not present among Upper Sorbian words at the time of the compilation of the dictionaries.

Semantically speaking, the dictionaries under scrutiny also provide examples of neo-semantization/anglosemantization of native Upper Sorbian words, that is a modification of the lexemic senses due to the influence of foreign words (cf. Witalisz 2007: 17). The most frequently adduced example of the influence of the semantics of net and mouse upon other languages is eloquently registered in the dictionaries. According to the lexicons, the Upper Sorbian words syć (as an equivalent of web vs. pawčina in JHŠS) and myška (in podłoha za myšku in JSSZŠ) have broadened their meanings to cover the assimilated senses of their English counterparts. 


\section{Conclusion}

The analyzed dictionaries show the presence of English loanwords in the vocabulary of Upper Sorbian, thanks to which we can establish a significant number of Anglicism in the language and observe the adaptation processes. Due to the lack of exhaustive information, however, we cannot fully account for the nature of these processes in Upper Sorbian: the dictionaries do not include phonetic information about the pronunciation of English borrowings, the information about inflection and gender assignment is too limited and the precise semantic descriptions of the borrowed items could be extended. In assessing the assimilation of English lexical items in Upper Sorbian we have to rely on the general nature of the adaptation processes in borrowings and resort to a knowledge of German and Upper Sorbian. Such an analysis of English loanwords in the selected Upper Sorbian English / English - Upper Sorbian dictionaries allows us not only to determine the number of Anglicisms in this Slavonic language, the processes of adaptation in operation, but also to ascertain their diachronic development and presentation in Sorbian lexicography, as well as to compare the lexicographic description of Anglicisms with their actual use. Lexicographic analyses of English borrowings in Upper Sorbian provide material for an examination of the assimilation of English words in closely related tongues (Upper vs. Lower Sorbian) as well as for comparative studies of Anglicisms in Upper Sorbian and English borrowings in other Slavonic languages.

\section{References}

HJS = Stone G. 2002. Hornjoserbsko-jendźelski słownik. Budyšin.

JHŠS = Wornar E. 2007. Jendźelsko-hornjoserbski šulski słownik. Budyšin.

JSSZŠ = Richardson K. 2009. Jendźelsko-serbskisłowničkzazakładnu šulu. [transl. Karichowa A.]. Budyšin.

SEESD = Strauch M. 2000. Sorbian [Wendish]-English/English-Sorbian [Wendish]. New York.

Adamska-Sałaciak A. 2013. Issues in compiling bilingual dictionaries. - Jackson H. (ed.).

The Bloomsbury companion to lexicography. London: 213-231.

Faska H. (ed.). 1998. Serbšćina. Opole.

Filipovič R. 1974. A contribution to the method of stuyding Anglicisms in European languages. - Studia Romanica et Anglica Zagrabiensia 37: 135-148.

Furiassi C. 2003. False Anglicisms in Italian monolingual dictionaries: A case study of some electronic editions. - International Journal of Lexicography 61.2: 121-142.

Görlach M. (ed.). 2005. A dictionary of European Anglicisms. Oxford.

Jentsch H., Pohontsch A., Schulz J. 2006. Deutsch-obersorbisches Wörterbuch neuer Lexik. Bautzen.

Kleparski G.A. 2001. Angielskie zapożyczenia leksykalne w języku polskim i niektóre problemy ich adaptacji. - Zeszyty Naukowe Wyższej Szkoły Pedagogicznej w Rzeszowie 42. Studia Anglica Resoviensia 2: 18-28.

Kovács É. 2008. On the integration of Anglicisms into Present-Day German. - Eger Journal of English Studies 8: 75-92. 
Kowner T., Rosenhouse J. 2008. The hegemony of English and determinants of borrowing from its vocabulary. - Rosenhouse J., Kowner R. (eds.). Globally speaking: Motives for adopting English vocabulary in other languages. Clevendon: 4-19.

Langerowa A., Šołćina B. 2007. Wot A do Ž. Słowničk za zakładnu šulu. Budyšin.

Obara J. 1989. Teoretyczne problemy kalkowania. Wrocław.

Onysko A. 2004. Anglicisms in German: From iniquitous to ubiquitous? - English Today 1:59-64.

Onysko A., Winter-Froemel E. 2011. Necessary loans - luxury loans? Exploring the pragmatic dimension of borrowing. - Journal of Pragmatics 43: 1550-1567.

Szpila G. [forthcoming]. Zapożyczenia angielskie we współczesnym pisanym języku łużyckim.

Völke S. 2006. Aktualne tendencje rozwojowe w górnołużyckim języku literackim. - Zeszyty Łużyckie 39/40: 37-49.

Völkel P. 2005. Prawopisny słownik hornjoserbskeje rěče. Budyšin.

Wanzeck C. 2010. Lexikologie. Göttingen.

Witalisz A. 2007. Z problematyki badań nad zapożyczeniami semantycznymi. - Język Polski 87.1: 16-23. 